\title{
Mapping the State of the Art on Green Logistics and Institutional Pressures: A Bibliometric Study
}

\author{
Tiago Henrique de Paula Alvarenga ${ }^{1}$, Carlos Manuel Taboada Rodriguez ${ }^{1} \&$ Claudia Cecilia Peña-Montoya ${ }^{2}$ \\ ${ }^{1}$ Postgraduate program in Production Engineering and Systems, Universidade Federal de Santa Catarina, \\ Florianópolis, Brazil \\ ${ }^{2}$ Universidad Santiago de Cali, Colombia and Universidad Autonoma de Occidente de Cali, Colombia \\ Correspondence: Campus Reitor João David Ferreira Lima, Centro Tecnológico, Universidade Federal de Santa \\ Catarina, Florianópolis, SC., 88040-900, Brazil. Tel: 55-48-3721-7003. E-mail: thpalvarenga@hotmail.com
}

Received: April 25, 2018 Accepted: May 27, 2018 Online Published: May 29, 2018

doi:10.5539/emr.v7n2p1 URL: http://doi.org/10.5539/emr.v7n2p1

\begin{abstract}
This article aims to build knowledge on the theme "green logistics" and "institutional pressures", focused on identifying opportunities on its research topic. We used the ProKnow-C intervention instrument, resulting in the selection of 11 relevant articles that came to represent the bibliographic portfolio. Therefore, the bibliometric indicators based on the most prominent journals, the impact factor, the number of citations, the origin of the research centers, the research methods/tools, the most used terms and the subjects covered were used to analyze the articles selected. research in the form of networks. The results showed that the most prominent journal is the International Journal of Production Economics; the article with the largest number of citations (343 citations) is written by Sameer Kumar and Valora Putnam. In relation to the origin of the research centers there was a diversity of institutions of various nationalities, the USA being the country with the largest number of institutions, followed by United Kindon and Malaysia. As for the research methods, we have identified literature reviews, case studies, surveys, conceptual framework proposal and monitoring system development. In relation to the mapping and research networks, we highlight terms such as logistic, regulatory pressure, practice, driver, economic performance, institutional pressure, among other relevant terms. In this context, this information can "shed light" on interested parties and researchers on the subject in order to conceptualize, interpret and visualize their relevance, as well as the coverage networks and related researches.
\end{abstract}

Keywords: bibliometrics, systematic reviews, green logistic, institutional pressures, bibliometric indicators.

\section{Introduction}

The theme of green logistics has become a hot topic nowadays due to the growing demands for environmental care in productive activities. This is largely due to the fact that most products consumed in more developed regions have their resource materials in most cases provided by distant regions (Lai \& Wong, 2012), making logistics activities very attention to environmental requirements (Richardson, 2001).

Green Logistics is concerned with producing and distributing goods in a sustainable manner, taking environmental factors into account. In it, the objectives do not refer only to the economic impact of logistics policies on the organization that performs them, but also to the broader effects on society, such as the effects of pollution on the environment. Green Logistics activities include measuring the environmental impact of different distribution strategies, reducing energy consumption in logistics activities, reducing waste and managing its waste (Sbihi \& Eglese, 2010).

In this context, the management of these green activities within logistics also considers the return and recycling of products, environmental management systems and ecoefficiency. This green logistics management enables conservation of natural resources, waste reduction, and even meets social expectations of environmental protection (Lai \& Wong, 2012). Although logistic activities impact the environment in some way or another, the inclusion of green logistics activities enables a significant reduction of this impact (Guide, 2000).

Classical logistics and traditional production and distribution models concentrate on minimizing costs subject to operational constraints, leaving aside environmental issues. Thus, increasing environmental demand defines that current logistic practices will not meet the environmental demands of the future (Sbihi \& Eglese, 2010). The 
need for a logistic transformation concerns not only the provision of green products or services to customers, but also the global logistic flow of items from the cradle to the grave, along with reverse logistics activities (Zhou, 2000).

Globalization of production has highlighted the importance of green logistics management in preventing environmental damage caused by product manufacturing and distribution activities (Lai \& Wong, 2012). This has led many organizations to assess their carbon footprint so that the environmental impact of their activities can be monitored. Governments are considering emission reduction targets and other environmental measures. There is, therefore, a growing interest in Green Logistics by governments and by their own organizations. (Sbihi \& Eglese, 2010).

The growth of this interest is a reflection of the environmental issues that within the organizational limits have been cause for concern and analysis. These issues range from reactive concerns to regulatory legislation to more proactive concerns, including building competitive advantages and developing a strong and ecological corporate image (Sarkis, 2012).

This environmental interest comes from pressures exerted by institutional agents that in many cases have been useful to raise the organizations' environmental performance, in terms of competitiveness and compliance with legal requirements (Delmas \& Toffel, 2004). These institutional pressures are considered as an important driver for the inclusion of management activities (Rivera, 2004), such as green activities in logistics management (Sarkis, Zhu \& Lai, 2011).

The Institutional Theory has provided a greater understanding of organizational phenomena, especially regarding the reaction of organizations to the institutional pressures of the environment in which they are inserted. These pressures may come from governmental regulatory agencies (regulatory pressure), from the market and from successful competitors (mimetic pressure) and from the organization itself and its professionalization (normative pressure) (Dimaggio \& Powell, 1983; Zhu et al., 2010). This theory deals with institutionalism, where organizations are led to incorporate practices and procedures (green activities) defined by concepts that predominate in the organizational environment and which are accepted, required and institutionalized in society (Meyer \& Rowan, 1977). Recently, this theme has supported the studies and provided an understanding of what motives influence organizations to have a green behavior (Sarkis, Zhu \& Lai, 2011).

Whence, the research question guiding this study is: How to research and select relevant data and information on Green Logistics and Institutional Pressures, aligned with the needs and delimitations of their researchers, taking into account the fact that they have a knowledge in development of this research topic?

Thus, the general objective of this research is to collect data on this topic and select a bibliographic portfolio (BP) of international scientific publications on "Green Logistics" and "Institutional Pressures", in line with the delimitations established by the researchers.

It is hoped that this general objective will be achieved through the achievement of specific objectives related to the research theme: selection of the most relevant articles, aligned with the research theme; And presentation of the most prominent journals, articles, institutions, methods and most used terms.

In order for the research question to be answered, the research tool used is the Knowledge Development Process - Constructivist (ProKnow-C), since this tool allows the realization of all the steps of the selection and bibliometry process, with visibility and repeatability , using a constructivist approach (Sartori et al., 2014).

\section{Method}

The method of the present research was bibliometry. This method deals with the study of the characteristics of scientific publications (Pritchard, 1969). For that, the quantitative aspects of the production, dissemination and use of the registered information are considered. This research modality is applicable in all areas of knowledge. In specific areas such as managed sciences and operations management, this method has been widely used. Researches such as those by Lacerda, Ensslin \& Ensslin (2014); Dutra et al. (2015); Rosa et al. (2012); Loss, Merino and Rodriguez (2016) prove this statement.

The instrument used to obtain the data was based on the Knowledge Development Process - Constructivist (ProKnow-C), proposed by Tasca et al. (2010), and used in researches such as Afonso et al. (2011); Ensslin et al. (2017); Sartori et al. (2014); Loss et al. (2016); Lacerda et al. (2014); Dutra et al. (2015); Rosa et al. (2012).

The ProKnow-C process comprises four stages: BP selection; bibliometric analysis; Systematic analysis; and research questions and objectives (Ensslin et al., 2017). In the present research, it is emphasized that the directions were inspired by the two initial stages of ProKnow-C. By means of these, two scripts were elaborated 
for the accomplishment of the research. It is the "selection of the Bibliographic Portfolio" that will provide the literature review and the "bibliometric analysis of the Bibliographic Portfolio" that will provide the analysis of the results.

\subsection{Selection of Bibliographic Portfolio}

To develop a work and build knowledge, the first step of the researcher is to review the literature on the subject. The selection of the bibliographic reference through ProKnow-C is carried out in a recursive way composed of the following stages: a) definition of the scientific articles in the databases; b) establishment of a Bank of Raw Articles, filtering and selection of the relevant Bibliographic Portfolio and aligned with the researcher's theme (Afonso et al., 2011, Ensslin et al., 2017).

\subsubsection{Selection of the Bank of Raw Articles}

In order to define the database of raw articles, one begins with the determination of the axes of the research, according to the researcher's perception. In this work, there are two lines of research: "Green Logistics" and "Institutional Pressures". The selection of the Gross Articles Bank is composed of: a) Definition of the keywords - Table 1; b) Definition of the databases: ISI Web of Knowledge; Science Direct; Springer Link; Willey Online Library and Emerald Insight. Regarding the content of these five databases, it is recorded that the keyword combinations were searched, using the field (article title), briefind (abstract), topic and keywords, ; c) Survey of the articles in the databases with the keywords: after completing the search of the keywords in the five databases, the publications were selected to compose the Bibliographic Portfolio called the Gross Articles Bank.

For a more complete coverage of articles, other search terms such as "Environmental Logistics" were used, according to Gonzalez-Benito and Gonzalez-Benito (2006), Gonzalez-Benito and Gonzalez-Benito (2008), Björklund, Martinsen and Abrahamsson, Green and Wagner (2005), Wolf and Seuring (2010) and "Ecological Logistics", according to Rogers and Tibben-Lembke (1999), Vahabzadeh, Asiaei and Zailani (2015) the same phenomenon, but with a different nomenclature.

The term "Reverse Logistics" was also included in the search since authors such as Ying and Li-Jun (2012), De Brito and Van Der Laan (2003), Hervani, Helms and Sarkis (2005), Sbihi and Eglese affirm that reverse logistics is a part of the large area of green logistics. The keywords are set out in Table 1:

Table 1. Used keywords in search

\begin{tabular}{lll}
\hline green logistics & and & institutional pressures \\
\hline green logistics & and & institutional theory \\
environmental logistics & and & institutional pressures \\
environmental logistics & and & institutional theory \\
reverse logistics & and & institutional pressures \\
reverse logistics & and & institutional theory \\
ecological logistics & and & institutional pressures \\
ecological logistics & and & institutional theory \\
\hline
\end{tabular}

\subsubsection{Raw Material Bank Filtering}

In the filtering process of the Gross Articles Bank, the 220 publications were analyzed for the following aspects: a) repeated articles; b) titles of articles aligned with the research theme; c) articles with scientific recognition; d) summaries aligned to the research topic; and, e) full text of articles aligned with the research topic.

The spreadsheet was used for the tabulation of selected publications in the databases searched. In the redundancy analysis duplicate articles were removed, leaving 129 articles in the Raw Bank Articles.

Analyzing the alignment of the title in relation to the research theme, a large number of articles were detected outside the relationship between "Green Logistics" and "Institutional Pressures". Thus, there were 26 non duplicate articles with a title aligned to the research topic, which were submitted to scientific recognition in Google Scholar. For the purposes of this analysis, scientific recognition of an article is understood to be the number of citations found after consultation with Google Scholar.

Then, the 26 articles selected were analyzed in relation to the alignment of the abstract and later to the full text 
with the research theme. Of the 26 articles, 2 articles did not have the full text available for reading, but were deleted. The other 24 articles had their texts analyzed in their entirety, and then 13 articles were excluded because they were not aligned. The remaining 11 articles were considered relevant and aligned to the theme and made up the Bibliographic Portfolio of the research (Appendix).

For these articles of the Bibliographic Portfolio, we present the descriptive analysis and characteristics in terms of the selection of the most prominent journals, impact factor, number of citations, origin of research centers, research methods/tools, terms used and topics covered in research.

\subsection{Bibliometric Networks}

The idea of visualizing networks or mapping of science has received much attention since the earliest bibliometric research (Van Eck \& Waltman, 2014). Visualization has become an important approach for analyzing a wide range of information, such as citation relationships, key issues, or key words (Cobo et al., 2011).

In this context, given the articles selected in this research, we sought to map the most used themes. It was used the similarity mapping (VOS) mapping technique, implemented as a computer program called VOSviewer (http://www.vosviewer.com/), University of Leiden, The Netherlands (Van Eck \& Waltman, 2007). To generate this scientific map, representing by labels (or density of visualization) and cluster, the summaries and titles of the articles of the portfolio were used.

\section{Analysis of Results}

We present the analysis of the characteristics of the articles that formed the Bibliographic Portfolio aligned to the two research axes: "Green Logistics" and "Institutional Pressures". These characteristics refer to the most prominent journals, impact factor and the scientific recognition of articles, origin of research centers, research methods/tools, most used terms and topics covered in the research.

\subsection{Bibliometric Analysis}

The bibliometric analysis of the Bibliographic Portfolio consists of the collection of statistics of the defined set of articles for information management and scientific knowledge of the research theme (Ensslin, Ensslin, \& Pacheco, 2012). The main objective of bibliometric analysis is to arrive at a set of consistent indicators (Van Raan, 2005). The analysis of the Bibliographic Portfolio was developed in five stages: i) to evaluate the degree of relevance of the periodicals; ii) evaluate the scientific recognition of articles; iii) origin of the research institutions present in the Bibliographic Portfolio; iv) research methods and tools used; and v) evaluate the most used terms.

Evaluating the degree of relevance of journals refers to identifying in which journal the largest number of articles among those that compose the Bibliographic Portfolio was published. There were 7 different journals, among them the International Journal of Production Economics, with 4 articles published (Figure 1).

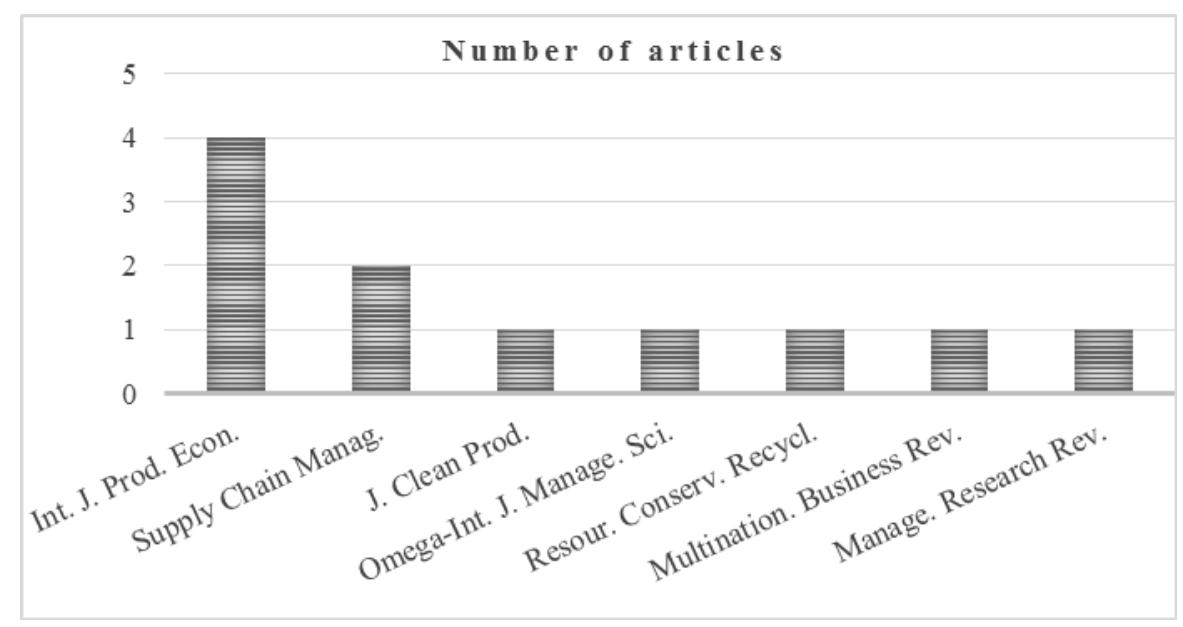

Figure 1. Number of articles per journals 
As a complement to the degree of relevance of journals, we searched the Journal Citations Reports (JCR) index of journals that formed the Bibliographic Portfolio. The JCR provides a perspective for periodic evaluation and comparison through the accumulation and tabulation of citation counts. It is a globally accepted and respected index. Figure 2 presents the indexes for the year 2016 of the journals of the Bibliographic Portfolio:

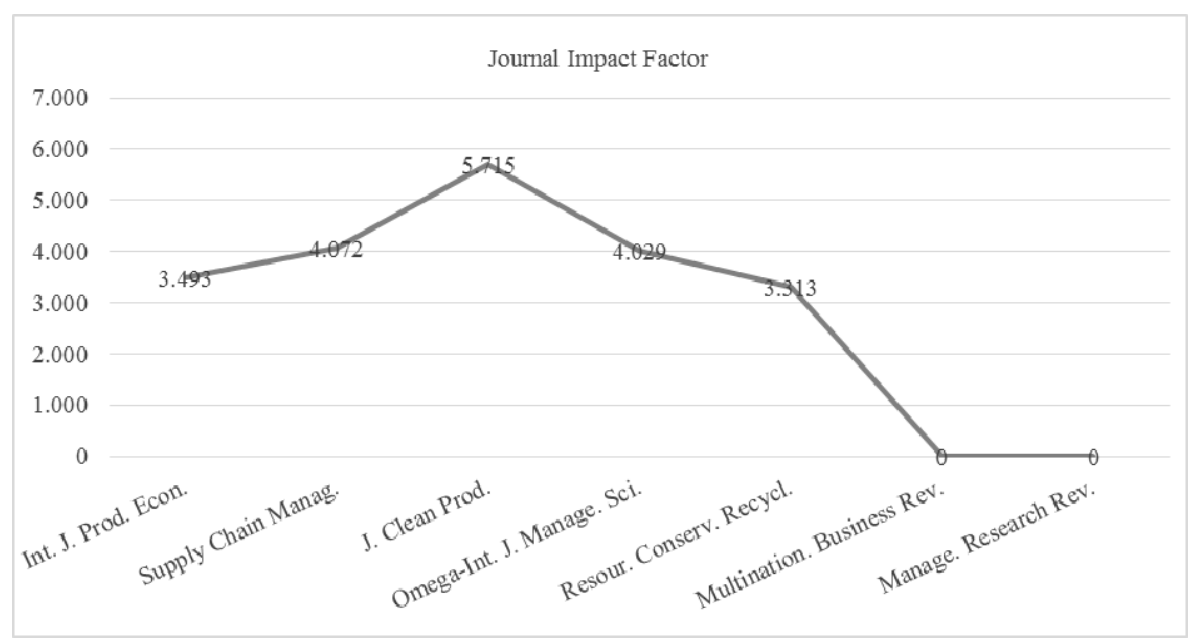

Figure 2. Journal impact factor (2016) of BP journals

Of the articles in the Bibliographical Portfolio (Appendix), the "Journal of Cleaner Production" with the index of 5.715, followed by Supply Chain Management with 4.072 and the Journal - "Omega: The International Journal of Management Science" with 4.029, being these three journals with the highest indexes of the Bibliographic Portfolio. The Multinational Business Review journals and the Management Research Review do not have an impact factor index - Journal Citation Reports (JCR).

As for the degree of scientific recognition of the articles that make up the Bibliographic Portfolio (see Appendix), a query was made regarding the number of citations of the articles in the Google Scholar databases, according to Loss, Merino and Rodriguez (2016); Sartori et al. (2014); Afonso et al. (2011). In evaluating the scientific recognition of articles in the Bibliographic Portfolio (Figure 3), the following articles stand out: "Cradle to cradle: Reverse logistics strategies and opportunities across three industry sectors", by Sameer Kumar and Valora Putnam, with 343 citations; and "Green logistics management and performance: Some empirical evidence from Chinese manufacturing exporters" by Kee-hung Lai and Christina W. Y. Wong with 217 citations. 


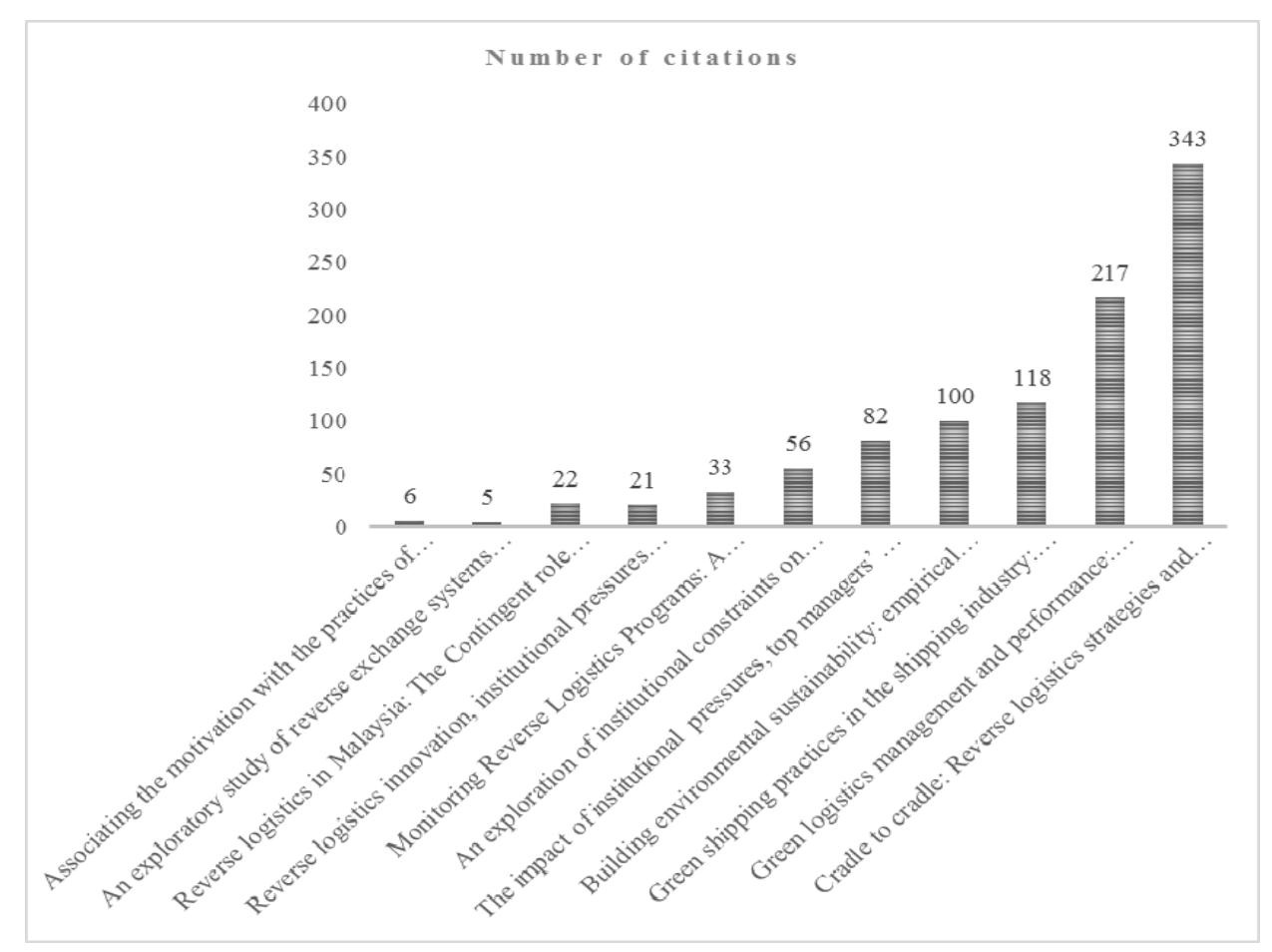

Figure 3. Number of articles citations

As for the origin of the research institutions present in the articles of the Bibliographic Portfolio, it is noted that the USA has the largest number of institutions, seven in all, being the University of St. Thomas; The University of Alabama; James Madison University; University of Illinois; University of Mississippi; University of Tennessee and Michigan State University.

The UK is also present with five institutions (Anglia Ruskin University, University of Bradford, University of Southampton, University of Greenwich, Hull University Business School), being the European representative with the largest number of institutions. From Europe, two more countries are also on the list. France with an institution (Audencia Nantes School of Management); and Italy also with a (Politecnico di Milano).

Asia was the continent with the largest number of countries. Malaysia was the country with the largest number of institutions in Asia, four in total, including Sunway University Business School; Universiti Utara Malaysia; Universiti Sains Malaysia Minden and Universiti Teknologi Malaysia Kuala Lumpur. China was also present with two research institutions (South China University of Technology, China-Europe International Business School), followed by Hong Kong with an institution (The Hong Kong Polytechnic University) and Taiwan with two institutions present (National Chengchi University, National Kaohsiung University of Applied Sciences).

Australia represented Oceania with a research institution on the list (Bond University). The origin and number of research institutions present in the articles of the Bibliographic Portfolio are presented according to Figure 4: 


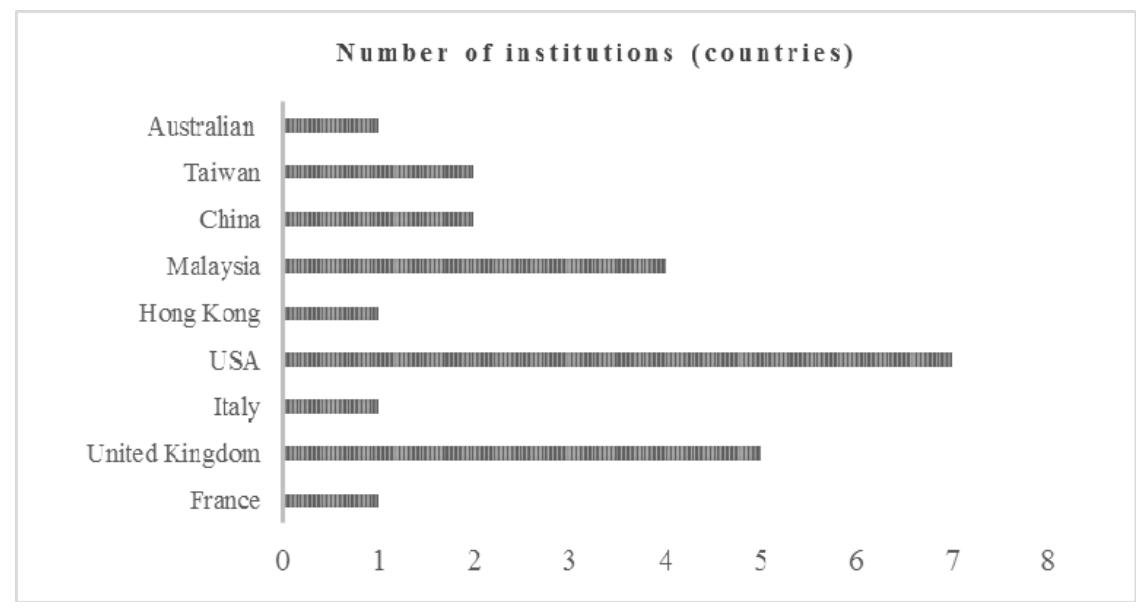

Figure 4. Number of institutions per countries

In relation to the methods used in the surveys, as well as the use of tools to obtain the data, we found heterogeneous methodological constructs. There are articles in the Bibliographic Portfolio, such as: literature review, case studies, surveys, proposal for a conceptual framework and development of a monitoring system. In relation to the possibilities of research on the conversion of the theme "Green Logistics" and "Institutional pressures", it is emphasized that there are immense possibilities both in its theoretical and empirical field. This is evidenced by the methodological diversification of the articles analyzed in this research. The methods/tools of the articles are presented in Table 2.

Table 2. Research method/tools

\begin{tabular}{ll}
\hline Article's code (see Apeendix) & Research method/tools \\
\hline A1 & Survey \\
B2 & Case study \\
C3 & Survey \\
D4 & Survey \\
E5 & Monitoring system development \\
F6 & Case study \\
G7 & Survey \\
H8 & Case study \\
I9 & A conceptual framework proposal \\
J10 & Survey \\
K11 & Literature Review \\
\hline
\end{tabular}

After analyzing the research methods and tools, the most important terms of the PB represented in figure 5 were mapped and in figure 6 the network was analyzed. Thus, we tried to map the most used themes. In order to generate this scientific map (Figure 5), represented by labels (or visualization density), the abstracts and titles of $\mathrm{BP}$ articles were used. It was used the similarity visualization mapping (VOS) technique through VOSviewer software. 


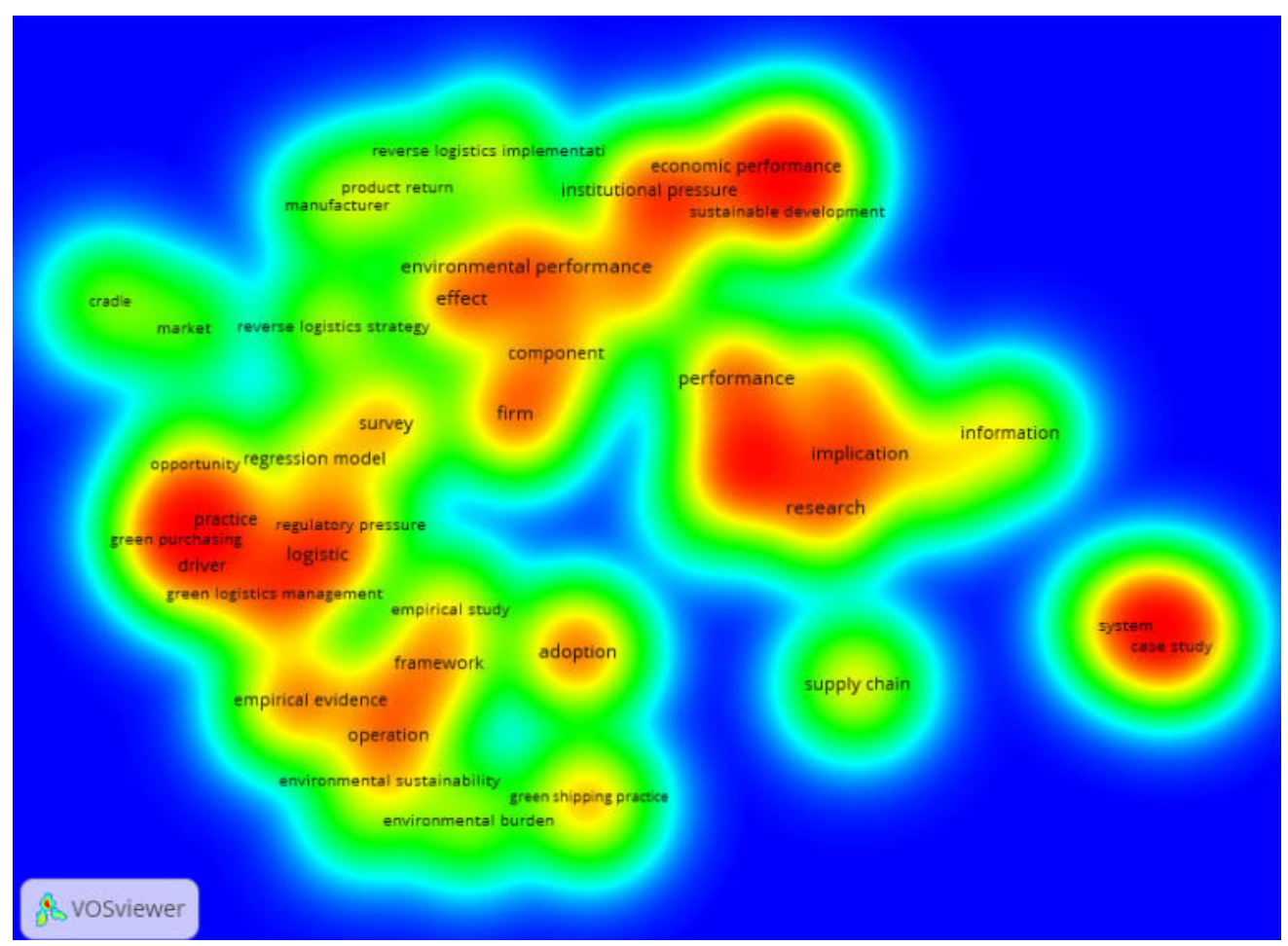

Figure 5. Display of labels

In Figure 5, what is noticed is that each term is represented by a label and also by a circle. The more important an element is, the greater its label and its corresponding circle. According to the results, the elements highlighted are: "economic performance", "institutional pressure", "environmental performance", "effect", "component", "firm", "practice", "driver" adoption "," performance "," implication "," system "and" case study ". According to Ercan and Cicekli (2011) this two-dimensional map allows visualizing the distance of the elements, reflecting their similarity with the highest possible precision.

Figure 6 represents the coverage of the subjects found in the portfolio articles about green logistics and institutional pressures. These terms are important since they represent the concepts that the authors wish to communicate and draw the attention of the readers/scientific community. According to Ercan \& Cicekli (2007), the terms are concise representations of a given text, which allows the reader to identify the scope and relevance of the theme.

Another important point to discuss is the density shown in figure 6. Since each node is directly connected to other nodes, its density reflects: (i) the complete extension of the network, (ii) the amplitude between the themes mentioned. For example, "environmental performance" has a low density when compared to "logistic" (strong color node). The same refers to the amplitude of the subject "performance" (blue color node), because the network demonstrates higher levels of communication with other subjects and very strong density. 


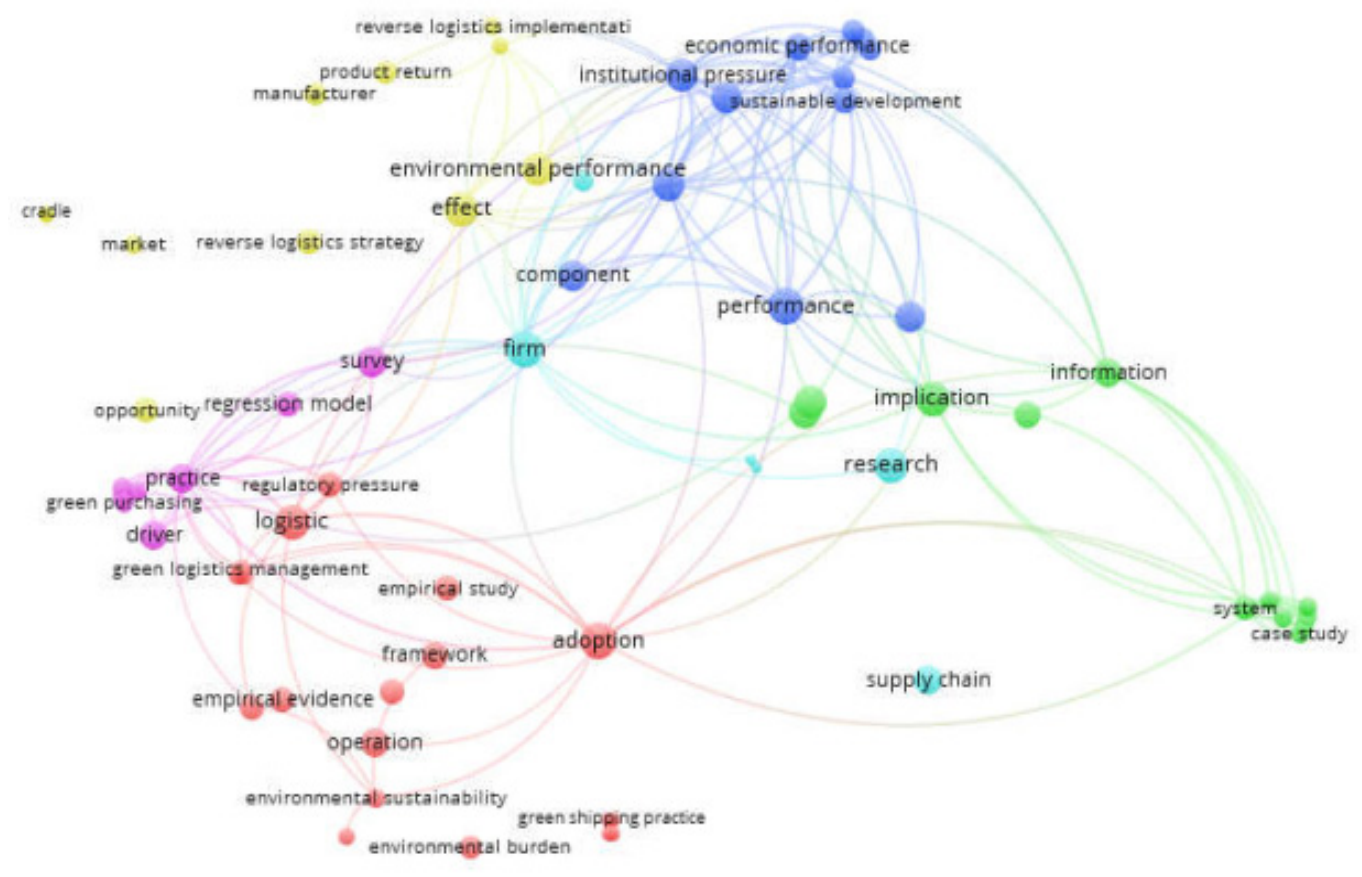

Figure 6. Network and themes nodes

Based on the scientific literature on the "hot topic" researched "Green Logistics" combined with "Institutional Pressures", it is noticeable that the blue cluster and the red cluster result in the themes and their variants of greater impact. That is, they are concepts that are often used in this field of study. Finally, we highlight that the six clusters related to research are in the color blue - economic performance, institutional pressures, sustainable development and performance; in yellow color - effect and environmental performance; in color lilac - survey, practice and driver; in color red - logistic, operation and adoption; in light blue color - firm and research; and in green color - implication, system and case study.

\section{Conclusions}

Green Logistics has advanced in the last decades, contributing to sustainable development, competitive advantages and generating new business opportunities. In turn, the growing diffusion of Green Logistics in business has drawn attention to what are the real reasons for its implementation. Recently the Institutional Theory emerged in the scientific community of Operations Management with in-depth studies on the industrial environment of companies and their conduct. This recent interest can be attributed to curiosities about the possible reasons for the implementation of green logistics, be they market practices, response to stricter legislation and/or values and professionalization of the companies themselves.

The present work was able to search and select relevant data and information on the coverage of the themes found in the articles of the bibliographic portfolio about "green logistics" and "institutional pressures". Scientific bibliometric research has received a lot of attention in recent years. The growth of information (indicators) on science is also remarkable from the different views on the coverage of certain subjects and from different perspectives.

The analysis made it possible to identify important indicators regarding the most relevant journals, number of citations, impact factor, origin of research centers, research methods/tools, terms used and subjects covered in the surveys. In addition, the analysis carried out in this research allowed us to address issues such as the main scientific research topics in the studies on "Green logistics" and "Institutional Pressures" and their relationships. The Proknow-C and VOSviewer procedure enabled the search process as it enabled the exploration, organization, and analysis of large masses of data for future research.

What is noticeable in the analysis of articles in the bibliographic portfolio is that institutional pressures have demonstrated their relevance in explaining the reasons that lead organizations to become green within the 
context of logistics. However, this work also showed that the use of the "green logistics" and "institutional pressures" relationship is still modest in the surveys, as evidenced by the number of articles present in the bibliographic portfolio, only eleven.

As research suggestions, it is suggested to search for different keywords in order to recover other important jobs in the area of green logistics directed to other topics. Future research can carry out different mappings and networks of relationships. Finally, these surveys may identify new indicators of bibliometric performance.

\section{Acknowledgments}

- We thank CNPq (National Council for Scientific and Technological Development - Brazil) for supporting research.

- The authors contributed symbiotically to each other.

\section{References}

Afonso, M. H. F. de Souza, J. V., Ensslin, S. R., \& Ensslin, L. (2012). How to build knowledge on the research topic? Application of the proknow-c process in the search for literature on sustainable development assessment. Journal of Social and Environmental Management, 5(2), 47-62.

Björklund, M., Martinsen, U, \& Abrahamsson, M. (2012). Performance measurements in the greening of supply chains. Supply Chain Management: An International Journal, 17(1), 29-39. https://doi.org/10.1108/13598541211212186

Cobo, M. J., Lopez-Herrera, A. G., Herrera-Viedma, E., \& Herrera, F. (2011). Science mapping software tools: Review, analysis, and cooperative study among tools. JASIST, 62(7), 1382-1402. https://doi.org/10.1002/asi.21525

De Brito, M. P., \&Van Der Laan, E. A. (2003). Inventory management with returns: the impact of misinformation. Erasmus research institute series. Rotterdam: Erasmus University Rotterdam.

Delmas, M., \& Toffel, M. W. (2004). Stakeholders and environmental management practices: An institutional framework. Business Strategy and the Environment, 13(4), 209-222. https://doi.org/10.1002/bse.409

DiMaggio, P. J., \& Powell, W. W. (1983). Iron Cage Revisited: Institutional Isomorphism and Collective Rationality in Organizational Fields. American Sociological Review, 48(2), 147-160. https://doi.org/10.2307/2095101

Dutra, A., Ripoll-Feliu, V. M., Ensslin, S. R., Ensslin, L., \& Gonçalves, L. R. P. (2015). Opportunities for research on evaluation of seaport performance: A systemic analysis from international literature. African Journal of Business Management, 9(20), 704-717. https://doi.org/10.5897/AJBM2015.7833

Ensslin, L., Ensslin, S.R., \& Pacheco, G. C. (2012). A study on safety at football matches based on the analysis of the international literature. Perspectivas em Ciências da Informação, 17(2), 71-91. https://doi.org/10.1590/S1413-99362012000200006

Ensslin, L., Ensslin, S. R., Dutra, A., Nunes, N. A., \& Reis, C. (2017). BPM governance: A literature analysis of performance evaluation. Business Process Management Journal, 23(1), 71-86. https://doi.org/10.1108/BPMJ-11-2015-0159

Evidence of the state of the art of the evaluation of work safety in civil construction projects. Interciencia, 39(1), $16-23$.

Ercan, G., \& Cicekli, I. (2007). Using lexical chains for keyword extraction. Information processing and management, 43(6), 1705-1714. https://doi.org/10.1016/j.ipm.2007.01.015

Gonzalez-Benito, J., \& Gonzalez-Benito, O. (2008). Operations management practices linked to the adoption of ISO 14001: an empirical analysis of Spanish manufacturers. International Journal of Production Economics, 113(1), 60-73. https://doi.org/10.1016/j.ijpe.2007.02.051

Gonzalez-Benito, J., \& Gonzalez-Benito, O. (2006). The role of stakeholder pressure and managerial values in the implementation of environmental logistics practices. International Journal of Production Research, 44(7), 1353-1373. https://doi.org/10.1080/00207540500435199

Guide, V. D. R. (2000). Production planning andcontrol for remanufacturing: industry practiceand research needs. Journal of OperationsManagement, 18(4), 467-483. https://doi.org/10.1016/S0272-6963(00)00034-6

Hervani, A. A., Helms, M. M., \& Sarkis, J. (2005). Performance measurement for green supply chain management. Benchmarking: An International Journal, 12(4), 330-53. 
https://doi.org/10.1108/14635770510609015

Kim, S. T., \& Lee, S. Y. (2012). Stakeholder pressure and the adoption of environmental logistics practices: is eco-oriented culture a missing link? International Journal of Logistics Management, 23(2), 238-258. https://doi.org/10.1108/09574091211265378

Lacerda, R. T. O., Ensslin, L., \& Ensslin, S. R. (2014). Research Opportunities in Strategic Management Field: A Performance Measurement Approach. International Journal Business Performance Management, 15(2), 158-174. https://doi.org/10.1504/IJBPM.2014.060165

Lai, K. H., \& Wong, C. W. V. (2012). Green logistics management and performance: some empirical evidence from Chinese manufacturing exporters. Omega: International Journal of Management Science, 40(3), 267-282. https://doi.org/10.1016/j.omega.2011.07.002

Loos, M. J., Merino, E., \& Rodriguez, C. M. T. (2016). Mapping the state of the art of ergonomics within logistics. Scientometrics, 109(1), 85-101. https://doi.org/10.1007/s11192-016-1960-z

Meyer, J. W., \& Rowan, B. (1977). Institutionalized organizations: formal structure as myth and ceremony. American Journal of Sociology, 83(2), 340-363. https://doi.org/10.1086/226550

Pritchard, A. (1969). Statistical Bibliography or Bibliometrics. Journal of Documentation, 25(4), 348-349.

Richardson, B. C. (2001). Freight trucking in a sustainable transportation system. Transportation Research Record, 1763, 57-64. https://doi.org/10.3141/1763-09

Rivera, J. (2004). Institutional pressures and voluntary environmental behavior in developing countries: evidence from the Costa Rican hotel industry. Society and Natural Resources, 17(9), 779-797. https://doi.org/10.1080/08941920490493783

Rogers, D. S., \& Tibben-Lembke, R. S. (1999). Going backwards: reverse logistics trends and practice. Reno: Reverse Logistics Executive Council.

Rosa, F. S., Ensslin, S. M., Ensslin, L., \& Lunkes, R. J. (2012). Environmental disclosure management: A constructivist case. Management Decision, 50(6), 1117-1136. https://doi.org/10.1108/00251741211238364

Sarkis, J. A. (2012). Boundaries and flows perspective of green supply chain management. Supply Chain Management: An International Journal, 17(2), 202-216. https://doi.org/10.1108/13598541211212924

Sarkis, J., Zhu, Q., \& Lai, K. H. (2011). An organizational theoretic review of green supply chain management literature. International Journal of Production Economics, 130(1), 1-15. https://doi.org/10.1016/j.ijpe.2010.11.010

Sartori, S., Ensslin, L., Campos, L. M. S., \& Ensslin, S. R. (2014). Literature review of environmental sustainability related to information technology. TransInformação, 26(1), 77-89. https://doi.org/10.1590/S0103-37862014000100008

Sbihi, A., \& Eglese, R. W. (2010). Combinatorial optimization and Green Logistics. Annals of Operations Research, 175(1), 159-175. https://doi.org/10.1007/s10479-009-0651-z

Tasca, J. E., Ensslin, L., Ensslin, S. R., \& Alves, M. B. M. (2010). An approach for selecting a theoretical framework for the evaluation of training programs. Journal of European Industrial Training, 34(7), 631-655. https://doi.org/10.1108/03090591011070761

Wolf, C., \& Seuring, S. (2010). Environmental impacts as buying criteria for third party logistical services. International Journal of Physical Distribution \& Logistics Management, 40(1/2), 84-102. https://doi.org/10.1108/09600031011020377

Van Raan, A. F. J. (2005). Measurement of central aspects of scientific research: Performance, interdisciplinarity, structure. Measurement, 3(1), 1-19. https://doi.org/10.1207/s15366359mea0301_1

Vahabzadeh, A. H., Asiaei, A., \& Zailani, S. (2015). Reprint of "Green decision-making model in reverse logistics using FUZZY-VIKOR method”. Resources, Conservation and Recycling, 104, 334-347. https://doi.org/10.1016/j.resconrec.2015.10.028

Van Eck, N. J., \& Waltman, L. (2007). VOS: a new method for visualizing similarities between objects. In H.-J. Lenz, \& R. Decker (Eds.), Advances in Data Analysis: Proceedings of the 30th Annual Conference of the German Classification Society. Springer. https://doi.org/10.1007/978-3-540-70981-7_34

Van Eck., N. J., \& Waltman, L. (2010). Software survey: VOSviewer, a computer program for bibliometric mapping. Scientometrics, 84(2), 523-538. https://doi.org/10.1007/s11192-009-0146-3 
Van Eck, N. J., \& Waltman, L. (2014). Visualizing bibliometric networks. In Y. Ding, R. Rousseau, \& D. Wolfram (Eds.), Measuring scholarly impact: Methods and practice. Springer. https://doi.org/10.1007/978-3-319-10377-8_13

Ying, J., \& Li-Jun, Z. (2012). Study on green supply chain management based on circular economy. Physics Procedia, 25, 1682-1688. https://doi.org/10.1016/j.phpro.2012.03.295

Zhang, S., Lee, C. K. M., Chan, H. K., Choy, K. L., \& Wu, Z. (2015). Swarm intelligence applied in green logistics: A literaturere view. Engineering Applications of Artificial Intelligence, 37, $154-169$. https://doi.org/10.1016/j.engappai.2014.09.007

Zhou, Z., Cheng, S., \& Hua, B. (2000). Supply chain optimization of continuous process industries with sustainability considerations. Computers \& Chemical Engineering, 24(2-7), 1151-1158. https://doi.org/10.1016/S0098-1354(00)00496-8

Zhu, Q., Geng, Y., Fujita, T., \& Hashimoto, S. (2010). Green supply chain management in leading manufacturers Case studies in Japanese large companies. Management Research Review, 33(4), $380-392$. https://doi.org/10.1108/01409171011030471 


\section{Appendix A}

Table A. Bibliographic Portfolio

\begin{tabular}{|c|c|c|c|}
\hline Article's code & Autors/year & Title & Journal \\
\hline A1 & $\begin{array}{l}\text { Sonia M. Lo and } \\
\text { Yu-Anne Shiah (2016) }\end{array}$ & $\begin{array}{l}\text { Associating the motivation with the } \\
\text { practices of firms going green: the } \\
\text { moderator role of environmental } \\
\text { uncertainty }\end{array}$ & $\begin{array}{lr}\text { Supply } & \text { Chain } \\
\text { Management: } & \text { An } \\
\text { International Journal } & \end{array}$ \\
\hline B2 & Ying Xie et al. (2016) & $\begin{array}{l}\text { An exploratory study of reverse } \\
\text { exchange systems used for medical } \\
\text { devices in the UK National Health } \\
\text { Service (NHS) }\end{array}$ & $\begin{array}{lr}\text { Supply } & \text { Chain } \\
\text { Management: } & \text { An } \\
\text { International Journal } & \end{array}$ \\
\hline $\mathrm{C} 3$ & Kuan Siew Khor (2016) & $\begin{array}{l}\text { Reverse logistics in Malaysia: The } \\
\text { Contingent role of institutional } \\
\text { pressure }\end{array}$ & $\begin{array}{l}\text { International Journal of } \\
\text { Production Economics }\end{array}$ \\
\hline D4 & $\begin{array}{l}\text { Yi-Chun Huang and } \\
\text { Min-Li Yang (2013) }\end{array}$ & \begin{tabular}{lcr} 
Reverse & logistics & \multicolumn{2}{c}{ innovation, } \\
institutional & pressures & and \\
performance & &
\end{tabular} & $\begin{array}{l}\text { Management } \\
\text { Review }\end{array}$ \\
\hline E5 & $\begin{array}{l}\text { R. Glenn Richey, Jr. et al. } \\
\text { (2005) }\end{array}$ & $\begin{array}{l}\text { Monitoring Reverse Logistics } \\
\text { Programs: A Roadmap to Sustainable } \\
\text { Development in Emerging Markets }\end{array}$ & $\begin{array}{l}\text { Multinational } \\
\text { Review }\end{array}$ \\
\hline F6 & Joe Miemczyk (2008) & $\begin{array}{l}\text { An exploration of institutional } \\
\text { constraints on developing end-of-life } \\
\text { product recovery capabilities }\end{array}$ & $\begin{array}{l}\text { International Journal of } \\
\text { Production Economics }\end{array}$ \\
\hline G7 & Fei Ye et al. (2013) & $\begin{array}{l}\text { The impact of institutional pressures, } \\
\text { top managers' posture and reverse } \\
\text { logistics on performance-Evidence } \\
\text { from China }\end{array}$ & $\begin{array}{l}\text { International Journal of } \\
\text { Production Economics }\end{array}$ \\
\hline $\mathrm{H} 8$ & $\begin{array}{l}\text { Claudia Colicchia et al. } \\
\qquad(2013)\end{array}$ & $\begin{array}{l}\text { Building environmental } \\
\text { sustainability: empirical evidence } \\
\text { from Logistics Service Providers }\end{array}$ & $\begin{array}{l}\text { Journal of } \\
\text { Production }\end{array}$ \\
\hline I9 & $\begin{array}{l}\text { Kee-Hung Lai et al. } \\
(2011)\end{array}$ & $\begin{array}{l}\text { Green shipping practices in the } \\
\text { shipping industry: Conceptualization, } \\
\text { adoption, and implications }\end{array}$ & $\begin{array}{l}\text { Resources, Conservation } \\
\text { and Recycling }\end{array}$ \\
\hline $\mathrm{J} 10$ & 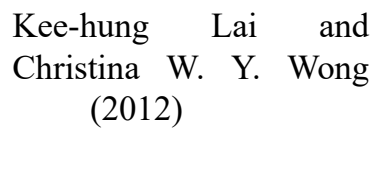 & \begin{tabular}{lrr} 
Green logistics & \multicolumn{2}{c}{ management and } \\
performance: & Some & empirical \\
evidence & from & Chinese \\
manufacturing exporters &
\end{tabular} & $\begin{array}{l}\text { Omega }-\quad \text { The } \\
\text { International Journal of } \\
\text { Management Science }\end{array}$ \\
\hline K11 & $\begin{array}{l}\text { Sameer Kumar and } \\
\text { Valora Putnam }(2008)\end{array}$ & $\begin{array}{l}\text { Cradle to cradle: Reverse logistics } \\
\text { strategies and opportunities across } \\
\text { three industry sectors }\end{array}$ & $\begin{array}{l}\text { International Journal of } \\
\text { Production Economics }\end{array}$ \\
\hline
\end{tabular}

\section{Copyrights}

Copyright for this article is retained by the author(s), with first publication rights granted to the journal.

This is an open-access article distributed under the terms and conditions of the Creative Commons Attribution license (http://creativecommons.org/licenses/by/4.0/). 